\title{
The Research on Environment Protection Knowledge and Competencies in Non-Formal Education
}

\author{
Nijole Jurksaitiene, Laima Markeviciene, Donatas Misiunas \\ Kauno kolegija/University of Applied Sciences, Faculty of Landscaping, Department of Green \\ Plantations and Agrotechnologies \\ Mokslo Street 2, Mastaiciai, 53313 Lithuania,E-mails: nijole.zak@gmail.com
}

\begin{abstract}
In Lithuania, as well as all over the world in developed countries, the society is starting to become a new kind of the information society. Under modern conditions it is increased the role of educated personality, personality capable of not only absorb the previously accumulated knowledge, but also to summarize, analyze, develop new and innovative ideas, information technologies, services and products. Implementing the EU common agricultural and rural development policy and adapting it to the local conditions, special attention must be paid to the qualitative aspects of human capital and education. Environment protection problems are deeply rooted in. The extensive agricultural policy of $\mathrm{EU}$ is in active formation process as a serious counterweight and feasible alternative to intensive, almost industrial farming [1]. According to this policy, farmers are supported for reducing negative impact on the environment and fostering an attractive landscape; therefore it is important to develop professional qualification. It is possible to distinguish three forms of education in formation of farmers' human resources: formal, non-formal and informal learning [2]. Formal education takes place in accordance with the statutory procedure, approved and registered training programs witch lead to the acquisition of a primary, secondary, or higher nonuniversity education and qualifications. Non-formal education is learning through a range of educational needs, training, and acquisition of additional skills. It typically involves workshops, community or interest based courses, conference style seminars. Informal education is continuous self-learning, based on the person gaining knowledge from various sources and practical experience. Non-formal and informal education is relevant to farmers who already have some formal education and seek to continually enhance and update their knowledge. Professional development is important to the farmer during all the farming period. The paper deals with environment protection competencies and qualification development gained during non-formal education course of farming basics. The study found out environment protection motivation and tendencies of knowledge use in practical activities.
\end{abstract}

Keywords: environment protection, non-formal education, competence, fundamentals of farming.

\section{INTRODUCTION}

The rapid society changes, economic reform, scientific and technical progress requires regeneration of environmental system in Lithuanian. Researches on environment protection are one of instrumentalities which have impact on changes of the urban environment and in general agriculture. Studies and collective action based on research results promote social changes. Ecology issues must be solved at national and cross levels. One of the most important tasks is to consistently educate ecological consciousness of adults. This must be visible for everyone and this approach should be developed from early years. Theoretical knowledge should be applied in order to protect natural resources. Finding acceptable organic forms of education in adult education, combining environmental cognition methods and techniques helps them reinforce the idea that people are not just consumers of nature, but each of us is responsible for the development and conservation of the environment. A number of scientists and educators worked in eco-education areas. J. M. Hines, I. Gabiavo prepared methodological materials and accumulated knowledge about environmental awareness. R. Repin, V. Lukankina, E.Sapokiene, A.Sidelkovskis, R.Makartsakaite, O. Motiejunaite investigated the effectiveness of various supplementary environmental education forms like clubs, radio shows, etc. Residential environment on ecological education studied V. Latiuskinas and I. Coriander. L. Keirans, P. Baltrunas, E. Sapokiene and others considered issues of ecological education researching students [8].

The aim of work is to assess the ecological importance of education, the need for developing environmental skills for adults.

The objectives of work:

1. To summarize development of organic farming in Lithuania and farm certification results.

2. To analyze training grounds and environmental motivation of the non-formal education courses listeners.

3. To evaluate environmental skills of non-formal education course listeners and to provide means of improving. 


\section{MATERIALS AND METHODS}

1. Theoretical: a systematic and comparative analysis of scientific literature, statistical comparative analysis.

2. Empirical: a survey (questionnaire).

\section{RESULTS AND DISCUSSION}

\section{Theoretical grounding of environmental skills' formation need.}

Nowadays, environment protection is widely recognized as a priority area. Ecologists, educators and andragogues have an important mission in environmental education. These are people who purposefully prepare young people to live with the changing labor market conditions. Environmental protection competencies of teachers and andragogues have influence on how young people will be able to create and work with new environment-friendly technologies.

Environment protection is taught as a separate subject or is integrated into various professions subjects. Environment protection is an important subject for any professional training [8].

Agricultural activities are considered multifunction, because here are the main functions of food, fiber, feed, energy, raw materials, and manufacturing, supplying private trade goods, carried out many other additional features. This is the vitality of rural areas, natural resources, biodiversity, cultural heritage, cultural landscape maintenance, food safety and quality assurance [4]. Goods (products or services) created by these functions are considered public and are generally non-marketable. People created public goods are produced as a product of human activity (cultural heritage, traditions and technological devices). Proportions of public values vary in different areas, they depend on nature and human interaction degree.

Residents of rural areas at the same time face several interrelated tasks:

- To produce agricultural products;

- To maintain adequate natural resources (soil, water, air) quality;

- To ensure food safety and quality;

- To preserve and maintain biodiversity, cultural (also natural) landscape;

- To preserve and maintain for new purposes rural material and spiritual heritage;

- To establish and properly operate rural infrastructure for public use. [1].

These tasks meet challenges as continuously ongoing migration of the population (Table 1). During the migration of the population in rural areas, changes in living conditions, the needs and provisions. These changes have the impact on the old and young rural habitants, both men and women.

TABLE 1

INTERNAL MIGRATION FLOWS (\%) IN 2009-2011 [5]

\begin{tabular}{|l|l|l|l|l|}
\hline $\begin{array}{l}\text { Year } \\
\text { Migration }\end{array}$ & 2009 & 2010 & 2011 & $\begin{array}{l}\text { Increase / decrease in 2011 } \\
\text { compared to 2009 }\end{array}$ \\
\hline Total urban arrivals & 30,1 & 30,3 & 31,8 & $+5,64$ \\
\hline urban-to-urban & 13,6 & 13,7 & 14,3 & $+5,14$ \\
\hline rural-to-urban & 16,5 & 16,6 & 17,5 & $+6,06$ \\
\hline Total rural arrivals & 19,4 & 19,5 & 20,3 & $+4,64$ \\
\hline urban-to-rural & 15,8 & 16,3 & 17,0 & $+7,59$ \\
\hline rural-to-rural & 3,6 & 3,2 & 3,3 & $-8,33$ \\
\hline
\end{tabular}

Based on data from first table, the number of internal migrants is increasing, as well as rural population mobility.

Environmental researches are one of the steps to change the situation of the urban environment and agriculture. Rural habitants comply best with the requirements of environment protection in organic farming, because the production line is closely related with their own viewpoint and way of life. The analysis of scientific literature and public institution "Ekoagros" data showed that organic farming in Lithuania in 2003-2007 increased rapidly gaining popularity and has stabilized lately. Despite this fact the certified organic area is growing. 158,060 hectares certified in 2011 [7]. Quantities and assortment of certified organic products was increasing. New processing plants was established, therefore number of organic raw materials and finished products exported to other EU countries.

The total area under organic farming increased, but the number of organic producers decreased in 20092011 (Fig. 1).

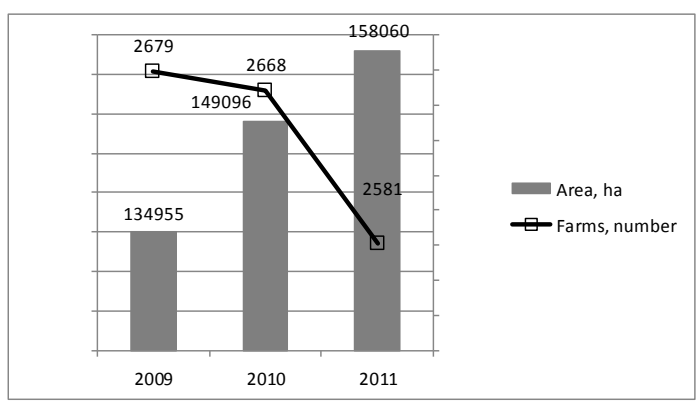

Fig. 1. Total organic area and farms (including fish farms), 20092011 [7] 
The average organic farm size is increasing every year. There are currently 61.2 ha organic farms, which are larger five times than the Lithuanian average. The number of certified farms owned by woman is increasing slowly (Fig. 2).

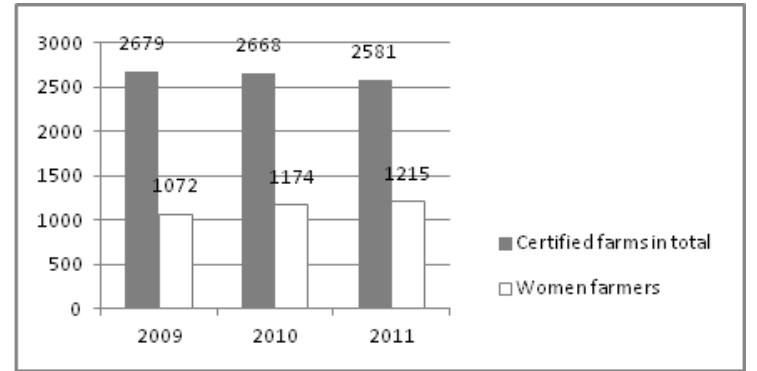

Fig. 2. The change in organic farms' number owned by women in 2009-2011 [7]

There are a lot of researches on organic production dealing with economic performance changes, the transition from conventional to organic production problems.

V.Grakauskas, Z.Gineitiene, J. Zvinklys, A. Poviliunas, E. V. Vabalas analysed organic farming as a business, A. Astromskienè, J. Ramanauskienè, R. Rukuižienè [3] analyzed rural entrepreneurship, its determinants and measures. Organic farming factors, their modeling studied V. Skulskis, V. Vitunskienè [6].

Environmental education is necessary condition for the implementation of sustainable development, replacing the consumerist approach to human resource and its values, unfortunately researches on farmers environmental approach is not much.

\section{A research on environmental knowledge and competencies gained during non-formal education course of farming basics.}

In 2010-2012, the research on environmental knowledge and competencies gained during nonformal education course of farming basics was carried out at Landscaping faculty of Kauno kolegija/University of Applied Sciences. The research involved 148 women and 256 men (Fig. 3).

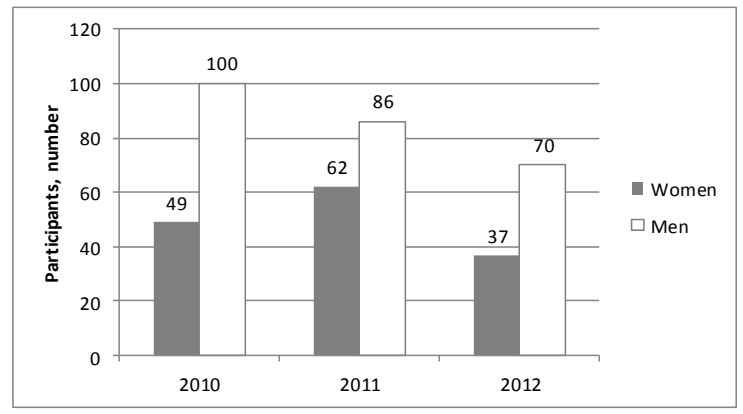

Fig. 3. Distribution of respondents by gender, 2010-2012

The survey results suggest that during analyzed period, percent of women in groups of listeners changed from 49 percent in 2010 to 72 percent in 2011.

A survey collected data about respondents' reasons for choosing non formal education (Fig. 4).

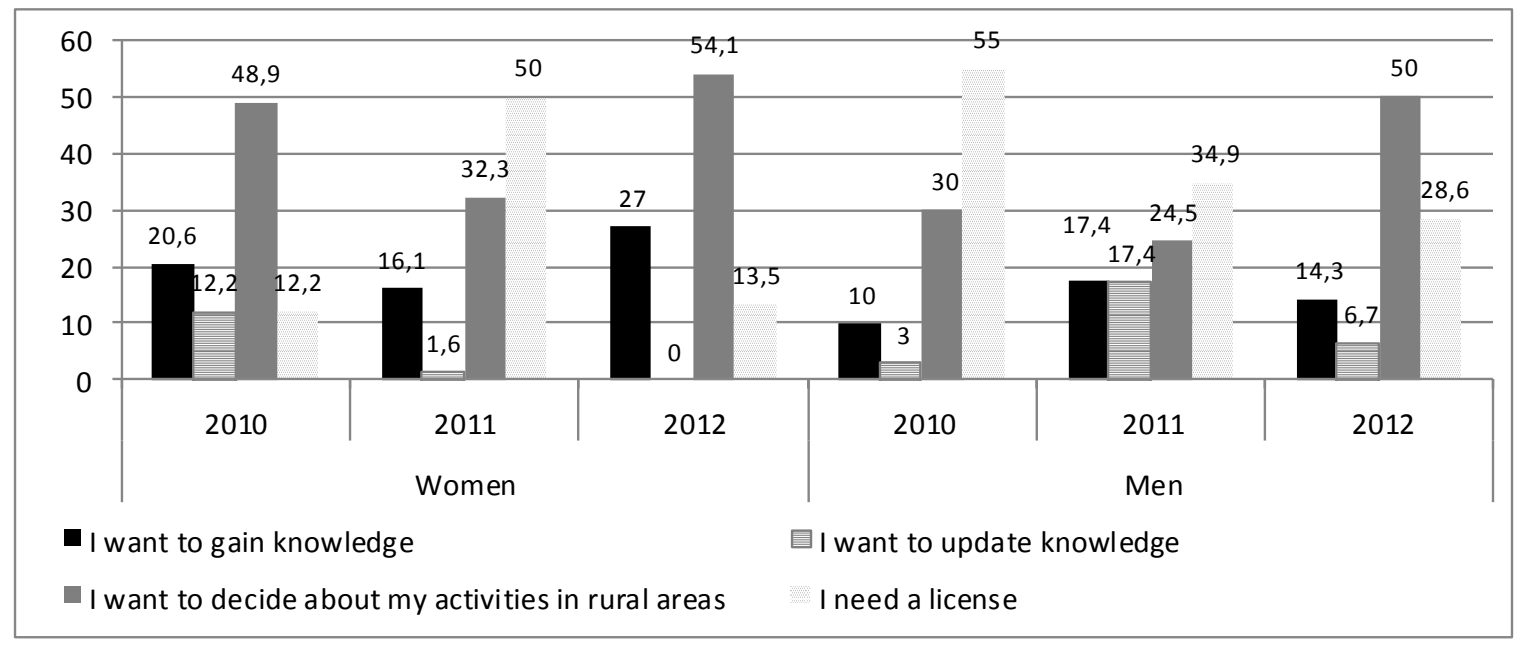

Fig. 4. Motives for the choice of non-formal education study

Analysis of the results suggests that the majority of respondents, both women and men, have chosen farming basics course because they need license or want to decide about their activities in rural areas.

The answers of respondents are not encouraging, because many of the respondents need a certificate only to build a country house, but the number of women who want to gain knowledge is increasing by about 10 percent every year.
Skilled and educated people from various regions were chosen as respondents, so it was important to determine motivation of the course choice.

During the analysis some environmental aspects were discussed. Respondents had to describe a number of environmental terms. Table 2 shows respondents' awareness of environmental concepts. 


\section{Jurksaitiene N., Markeviciene L., Misiunas D. THE RESEARCH ON ENVIRONMENT PROTECTION KNOWLEDGE AND COMPETENCIES IN NON-FORMAL EDUCATION}

TABLE 2

AWARENESS OF ENVIRONMENTAL CONCEPTS, \%

\begin{tabular}{|l|l|l|l|l|l|l|}
\hline \multirow{2}{*}{ Concepts } & \multicolumn{2}{|l|}{2010} & \multicolumn{2}{l|}{2011} & 2012 \\
\cline { 2 - 7 } & men & women & men & women & men & women \\
\hline Sustainable development & 20 & 48,9 & 34,88 & 32,25 & 28,57 & 27,02 \\
\hline Ecosystem & 50 & 24,5 & 34,88 & 50,0 & 57,14 & 54,05 \\
\hline Biodiversity & 30 & 48,9 & 50,0 & 58,06 & 50,0 & 59,45 \\
\hline "Agenda 21" & 5 & 12,2 & 11,62 & 16,12 & 14,28 & 18,90 \\
\hline Movement "Let's do it" & 90 & 100 & 100 & 100 & 100 & 100 \\
\hline
\end{tabular}

It can be seen from Table 2 that number of respondents is increasing every year (especially women), who are known to the terms listed. It should be noted that the best known concept is movement "Let's do it" (100 percent of women and 96.66 percent of men in 2009-2011). Women were aware of concept "Biodiversity" 12 percent more than men and concept "Agenda 21" more than 6 percent. Movement "Let's do it" is well known, but it turns a relatively small number of respondents (Table 3 ).

TABLE 3

RESPONDENTS' ATTITUDE TO THE MOVEMENT "LET's Do IT", \%

\begin{tabular}{|l|l|l|l|l|l|l|}
\hline \multirow{2}{*}{ Concepts } & \multicolumn{2}{|l|}{2010} & \multicolumn{2}{l|}{2011} & 2012 & \\
\cline { 2 - 7 } & men & women & men & women & men & women \\
\hline Yes, I participate every year & 0 & 24,5 & 5,81 & 32,25 & 28,57 & 27,02 \\
\hline I took part once & 20 & 36,7 & 34,88 & 32,25 & 28,57 & 40,52 \\
\hline I would like, but I do not have time & 60 & 26,6 & 53,5 & 35,5 & 28,58 & 26,96 \\
\hline I'm not interested & 20 & 12,2 & 5,81 & 0 & 14,287 & 5,50 \\
\hline
\end{tabular}

It can be seen from Table 2, that 28 percent woman and only 11.46 percent men each year participate in the movement "Let's do it". On average, 29.68 percent women and 47.36 percent men would like to participate but do not have time, only 4 percent female and 13.36 percent men were not interested in this movement.

An attitude to the environment begins with our individuality, the environment in which we live.
Therefore, it was important to find out respondents' practical experience in an environmental field. Responses received showed that even 69 percent women and 58 percent men believe that their way of life has a positive impact on the nature, the environment and society, but 20 percent women and 22.5 percent men do not realize about it (Table 4).

TABLE 4

PRACTICAL APPLICATIONS OF ENVIRONMENTAL KNOWLEDGE, \%

\begin{tabular}{|l|l|l|l|l|l|l|}
\hline \multirow{2}{*}{ Statements } & \multicolumn{2}{l}{2010} & 2011 & \multicolumn{2}{l|}{2012} \\
\cline { 2 - 8 } & men & women & men & women & men & women \\
\hline I save water & 45 & 55 & 55,81 & 66,12 & 64,28 & 67,48 \\
\hline I save electricity & 65 & 60 & 73,25 & 58,06 & 78,57 & 67,48 \\
\hline I sort waste & 5 & 45 & 11,62 & 32,25 & 14,28 & 40,52 \\
\hline I eat more fruits and vegetables & 5 & 75 & 11,62 & 90,31 & 28,57 & 81,07 \\
\hline I use eco-friendly laundry detergents & 0 & 30 & 5,81 & 32,25 & 7,14 & 40,52 \\
\hline $\begin{array}{l}\text { No longer needed clothing, shoes, toys, home appliances } \\
\text { I give to charities }\end{array}$ & 3 & 30 & 5,81 & 58,06 & 14,28 & 27,02 \\
\hline I use reusable shopping bags & & & & & & \\
\hline I do not use disposable hygiene products & 50 & 30 & 5,81 & 32,25 & 7,14 & 13,53 \\
\hline I use public transport, bicycle & 10 & 30 & 5,81 & 32,25 & 14,28 & 13,53 \\
\hline I teach children to love nature & 10 & 30 & 11,62 & 17,76 & 14,28 & 26,96 \\
\hline I handle environment where I live & 75 & 100 & 84,88 & 100 & 92,85 & 100 \\
\hline
\end{tabular}

The results suggest that the majority of respondents save water, electricity, maintenance of nature as well as teaching their children of environmental skills.
Women in the practical environmental activities are much more active than men. However, it is appropriate to promote a wider integrated theoretical 
and practical knowledge of environmental education, as there are little of the respondents, who sort wastes, are using eco washing, and cleaning, re-usable

When a follow-up question was asked about what kind of farming system respondent plan to choose, the results showed an increase in popularity of organic shopping bags. Completion of non-formal education courses creates preconditions for the respondents to live or work in rural areas.

farming among women and intensive agriculture popularity among men (Table 5).

TABLE 5

RESPONDENTS PERSPECTIVES ON CROPPING SYSTEMS, \%

\begin{tabular}{|l|l|l|l|l|l|l|}
\hline \multirow{2}{*}{ Cropping systems } & \multicolumn{2}{|l|}{2010} & \multicolumn{2}{l|}{2011} & \multicolumn{2}{l|}{2012} \\
\cline { 2 - 7 } & men & women & men & women & men & women \\
\hline Intensive farming system & 25,0 & 24,5 & 23,2 & 16,1 & 28,6 & 5,9 \\
\hline Organic farming system & 5,0 & 48,9 & 30,2 & 24,2 & 7,1 & 54,1 \\
\hline Subsistence farm & 10,0 & 20,5 & 11,6 & 30,2 & 14,3 & 13,5 \\
\hline Other & 60,0 & 6,1 & 34,8 & 29,4 & 50,0 & 27,0 \\
\hline
\end{tabular}

Focus on subsistence agriculture is associated with the respondents (about 30 percent responses) need to build a farm in the rural area and provide a healthy meal for family.

\section{CONCLUSIONS}

1. The analysis of scientific information and public enterprise "Ekoagros" data indicates that the certified organic area remained constant in 2011 and was 158,060 hectares in Lithuania. An average organic farm in the area is currently 61.2 hectares. There were growth of certified organic products not only in quantity but also the assortment, new refineries, a number of organic raw materials and finished products exported to other EU countries in 2009-2011. Also increased number of organic farms runs by women.

2. In 2010-2012, non-formal education course of farming basics was carried out at Landscaping faculty of Kauno kolegija/University of Applied Sciences. The research involved 148 women and 256 men.
Analysis of the results suggests that the majority of respondents have chosen farming basics course because they needed license. Course participants believe that their way of life has a positive impact on the environment, the environment and society.

3. The survey of their knowledge and skills in the field of environment presented that most of the respondents know the basic environmental provisions, but in practice for a variety of reasons do not implement. Women show initiative and are much more active in practical environmental performance. There is also increasing both: organic farming and women in the number of farms and popularity of nonformal education in organic farming courses in the audience of women. The environmental education aims are to provide the knowledge, abilities and skills, to develop interest in a particular activity. Therefore subject programs of farming basics course must be supplemented with environmental material, also basics of organic and exceptional quality production. 